\title{
Stream-Dwelling Fish Communities from an Atlantic Rain Forest Drainage
}

\author{
Rosana Mazzoni $^{1 *}$, Nelsy Fenerich-Verani ${ }^{2}$, Érica Pellegrini Caramaschi ${ }^{3}$ and Ricardo \\ Iglesias-Rios $^{3}$ \\ ${ }^{I}$ Departamento Ecologia; IBRAG; UERJ; Rua São Francisco Xavier, 524; 20550-013; Maracanã - RJ - Brasil. \\ ${ }^{2}$ Departamento Hidrobiologia; IB; UFSCar; São Carlos - SP - Brasil. ${ }^{3}$ Departamento Ecologia; IB; UFRJ; Rio de \\ Janeiro - RJ - Brasil
}

\begin{abstract}
Twenty-two species were registered in the Ubatiba system with a predominance of Characiformes and Siluriformes followed by Cyprinodontiformes, Perciformes and Synbranchiformes. Among these species four were occasional with one or two sampled individuals and restricted to one or two of the nine studied sites; the other 18 species were constant with high densities in at least one site. Most of the sampled sites presented between 11 and 18 species, all largely distributed; except for the uppermost site, located right over a waterfall $4 \mathrm{~m}$ high, which showed at least four species and for the confluence site that presented 18 species. Canonical Correspondence Analysis indicated that environmental variables explained a great part of the density and distribution patterns of the fish species, showing that community structure of each locality was independent from the longitudinal succession, theoretically expected by the River Continuum Concept, and hardly explained by local environmental characteristics.
\end{abstract}

Key words: Coastal stream, distribution, community structure, fish

\section{INTRODUCTION}

Fish communities have been interpreted according to species composition and/or diversity, as well as by distribution patterns that reflect the environmental resources availability (Bayley and $\mathrm{Li}$, 1992) and/or biological interactions between species (Matthews, 1998). Abiotic and biotic relationships are the major agents that affect species occurrence in a given environment. Abiotic ones can be explained through the history of geological and geomorphologic phenomena (Giller and Malmqvist, 2001), which determines some specific environmental conditions and provide local support for certain species. Biotic relationships, on the other hand, are expressed through specific qualities of populations, morpho and physiological adaptation to local conditions, and the inter-relationship between different species and a possible coevolution among them.

Most of the models that address river community structure and dynamics are largely based on patterns observed for temperate regions. Vannote et al. (1980) proposed the River Continuum Concept in order to explain riverine communities and stated that distribution and abundance of aquatic organisms is directly influenced by resources availability along the longitudinal gradient of fluvial systems. This model, however, neglects the water chemical quality and the biotic interactions (Angermeier and Karr, 1984) that

\footnotetext{
*Author for correspondence
} 
have been shown to be important parameters in freshwater communities.

The purpose of the present work was to describe the distribution and community structure of stream-dwelling fishes from a coastal fluvial system of a rain forest drainage in the southeast of Brazil (Ubatiba basin, Maricá - RJ).

\section{MATERIAL AND METHODS}

The Ubatiba river $\left(22^{\circ} 60^{\prime} \mathrm{S}\right.$ e $\left.42^{\circ} 48^{\prime} \mathrm{W}\right)$ forms a small fluvial system that drains the east watershed of Serra do Mar. It flows down through about 18 $\mathrm{km}$, and discharges itself into the Maricá lagoon system, located $70 \mathrm{~km}$ north of the metropolitan region of Rio de Janeiro. Agriculture and cattle breeding are responsible for the deforestation of lowlands along the river but there are still some small patches of original Atlantic rain forest in the headwaters.

Nine localities (Fig. 1), sampled bimonthly between July 1994 and July 1995, included five sites in the Ubatiba river: U1, U2, U3, U4 and U5 and one site in each of its four tributaries: Silvado $(\mathrm{Si})$, Caboclo $(\mathrm{Ca})$, Fundo (Fu) and Itapeteiú (It). Sampling sites were approximately $80 \mathrm{~m}$ long, and about $4 \mathrm{~km}$ apart from each other.

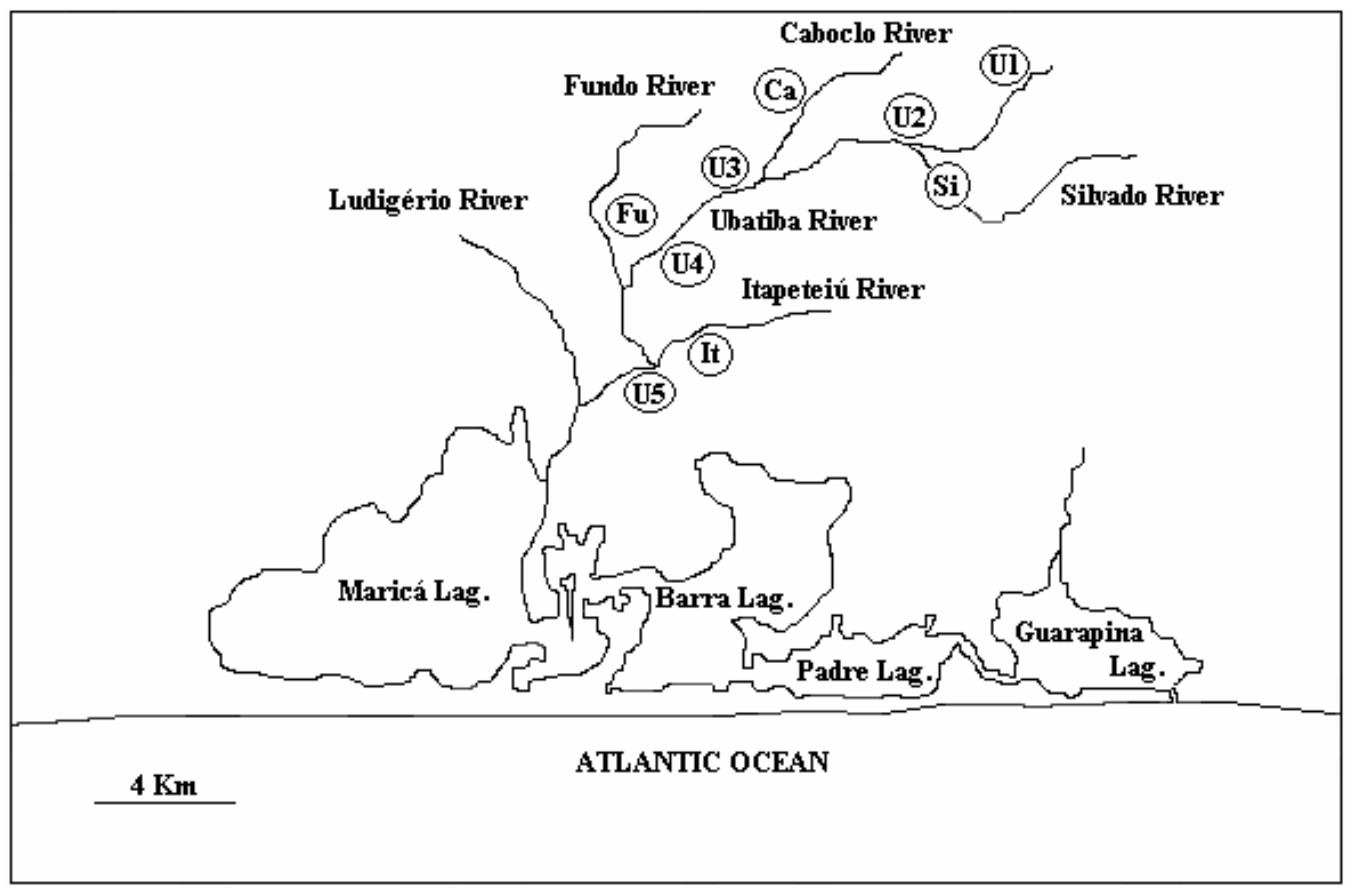

Figure 1 - Geographical location of the Ubatiba system $\left(22^{\circ} 50^{\prime}, 22^{\circ} 55^{\prime} \mathrm{S}\right.$ e $\left.42^{\circ} 43^{\prime}, 42^{\circ} 50^{\prime} \mathrm{W}\right)$ with indication of the sample sites at Ubatiba river (U1 to U5) and on each of its four tributaries ( $\mathrm{Si}, \mathrm{Ca}, \mathrm{Fu}$ and $\mathrm{It})$.

Samples were obtained by electrofishing $(900 \mathrm{~W}$, 2-3 A) through the three-removal method. At the end of the last removal, each captured fish was measured (standard length, $S L, \mathrm{~cm}$ ) and returned alive to the water. Fish abundance was estimated according to the Zippin Method (Zippin, 1958) and transformed into densities (ind.ha ${ }^{-1}$ ) based on the sampled area of each site. Sampled area was calculated for each sampling month and site, according to bathymetric maps based on transversal transects registered within an interval of $5 \mathrm{~m}$ long, from the lower to the upper section of the sampling site. Environmental parameters were also quantified within the same transects used for the sampling area estimates.

Patterns of interspecific covariation, between the seven sampling periods indicated a marked temporal persistence in the community structure of the nine studied sites and have been discussed elsewhere (Mazzoni and Lobón-Cerviá, 2000). Thus, community structure of each sampling site was based on the mean densities of the species that were constant and/or abundant. 
Table 1 - List of the 22 fish species and respective mean density (ind.ha ${ }^{-1}$ ) of the 9 sampling sites in the Ubatiba fluvial system during the whole sampling period. Species marked with $*$ are constant (frequency $>85 \%$ ) and of high densities.

\begin{tabular}{|c|c|c|c|c|c|c|c|c|c|}
\hline SAMPLING SITES & U1 & $\mathbf{U 2}$ & $\mathbf{U 3}$ & $\mathbf{U 4}$ & U5 & $\mathbf{S i}$ & $\mathbf{C a}$ & $\mathbf{F u}$ & It \\
\hline \multicolumn{10}{|l|}{ CHARACIFORMES } \\
\hline \multicolumn{10}{|l|}{ CRENUCHIDAE } \\
\hline * Characidium $\mathrm{sp}$ & 2,686 & 2,047 & & 77 & & 147 & & & \\
\hline * Characidium interruptum Pellegrin, 1909 & & 377 & 311 & 362 & 1,143 & 101 & 472 & 1,333 & 919 \\
\hline \multicolumn{10}{|l|}{ CHARACIDAE } \\
\hline \multicolumn{10}{|l|}{ Incertae Sedis in CHARACIDAE } \\
\hline * Astyanax janeiroensis Eigenmann, 1908 & 437 & 1,695 & 1,557 & 1,675 & 2,320 & 2,320 & 1,088 & 1,216 & 3,936 \\
\hline * Astyanax hastatus Myers, 1928 & & 6,324 & 6,346 & 10,246 & 22,580 & 5,205 & 7,578 & 6,186 & 30,535 \\
\hline Hyphessobrycon bifasciatus Ellis, 1911 & & & & & 21 & & & & \\
\hline * Hyphessobrycon reticulatus Ellis, 1911 & & & & & 74 & & & & 15 \\
\hline \multicolumn{10}{|l|}{ GLANDULOCAUDINAE } \\
\hline * Mimagoniates microlepis (Steindachner, 1876) & & 32 & & 816 & 909 & 2,045 & 14 & 10,708 & 1,876 \\
\hline \multicolumn{10}{|l|}{ ERYTHRINIDAE } \\
\hline *Hoplias malabaricus (Bloch, 1994) & & 660 & 651 & 209 & 631 & 181 & 304 & 117 & 313 \\
\hline \multicolumn{10}{|l|}{ SILURIFORMES } \\
\hline \multicolumn{10}{|l|}{ CALLICHTHYIDAE } \\
\hline * Callichthys callichthys (Linnaeus, 1758) & 248 & 25 & & 16 & & 32 & 424 & 48 & 39 \\
\hline \multicolumn{10}{|l|}{ LORICARIIDAE } \\
\hline \multicolumn{10}{|l|}{ LORICARIINAE } \\
\hline * Rineloricaria sp. & & & & & 211 & & & & 1,909 \\
\hline \multicolumn{10}{|l|}{ HYPOSTOMINAE } \\
\hline \multicolumn{10}{|l|}{ Incertae Sedis in HYPOSTOMINAE } \\
\hline * Hypostomus cf. punctatus Vallenciennes, 1840 & & 2,315 & 2,795 & 870 & 1,973 & 171 & 430 & & 2,267 \\
\hline \multicolumn{10}{|l|}{ HEPTAPTERIDAE } \\
\hline \multicolumn{10}{|l|}{ Incertae Sedis in HEPTAPTERIDAE } \\
\hline * Pimelodella lateristriga (Mueller and Troschel, 1849) & & 2,310 & 619 & 252 & 3,444 & 1,108 & 639 & 301 & 3,210 \\
\hline * Rhamdia sp. & & 213 & 92 & 72 & 471 & 163 & 266 & 93 & 411 \\
\hline \multicolumn{10}{|l|}{ CYPRINODONTIFORMES } \\
\hline \multicolumn{10}{|l|}{ RIVULIDAE } \\
\hline Rivulus janeiroensis Costa, 1991 & & & & & 9 & & & & 32 \\
\hline \multicolumn{10}{|l|}{ POECILIIDAE } \\
\hline * Phalloceros caudimaculatus (Hensel, 1868) & 14,304 & 52 & 25 & 37 & & 12,970 & 251 & 27,831 & 963 \\
\hline * Poecilia reticulata Peters, 1854 & & & & & 257 & & & 58 & 1111 \\
\hline * Poecilia vivipara Schneider, 1801 & & 22,582 & 7,407 & 4,723 & 12,411 & 348 & 2,929 & 14,257 & 2,912 \\
\hline \multicolumn{10}{|l|}{ ANABLEPIDAE } \\
\hline * Jenynsia multidentata (Jenyns, 1842) & & & & & 2,370 & & & & \\
\hline
\end{tabular}

SYNBRANCHIDAE

* Synbranchus marmoratus Bloch, 1795

$\begin{array}{llllll}95 & 36 & 61 & 43 & 40 & 161\end{array}$
167

\section{PERCIFORMES}

\section{CICHLIDAE}

* Geophagus brasiliensis (Quoy and Gaimard, 1824)

GOBIIDAE

$\begin{array}{llllllllll}\text { Species Diversity } & 4 & 14 & 11 & 15 & 18 & 14 & 13 & 12 & 16\end{array}$




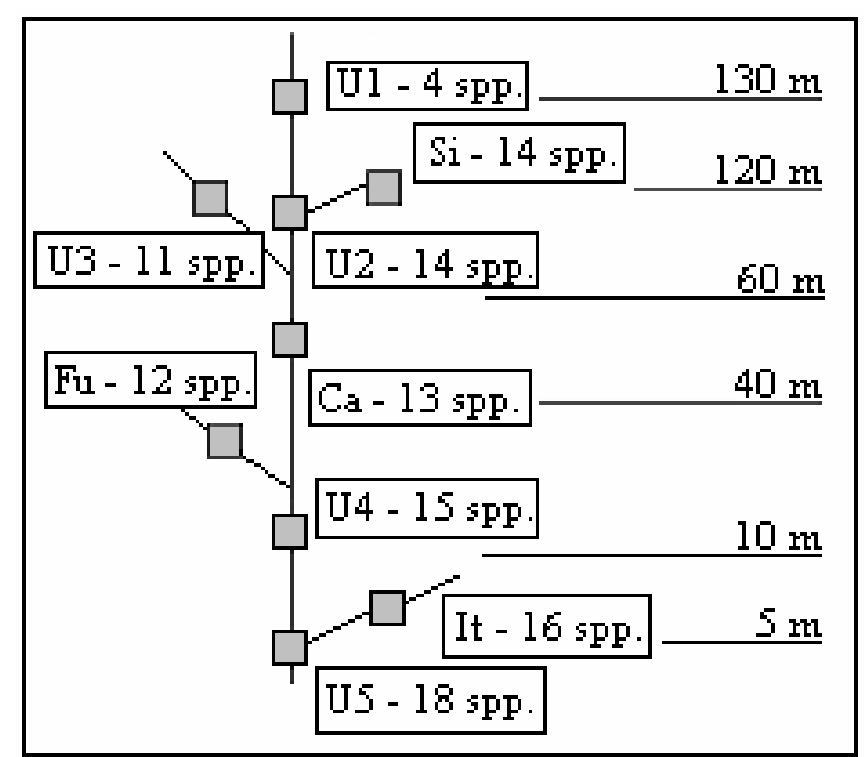

Figure 2 - Sketch representing the altitudinal position of the sampling sites and respective species diversity.

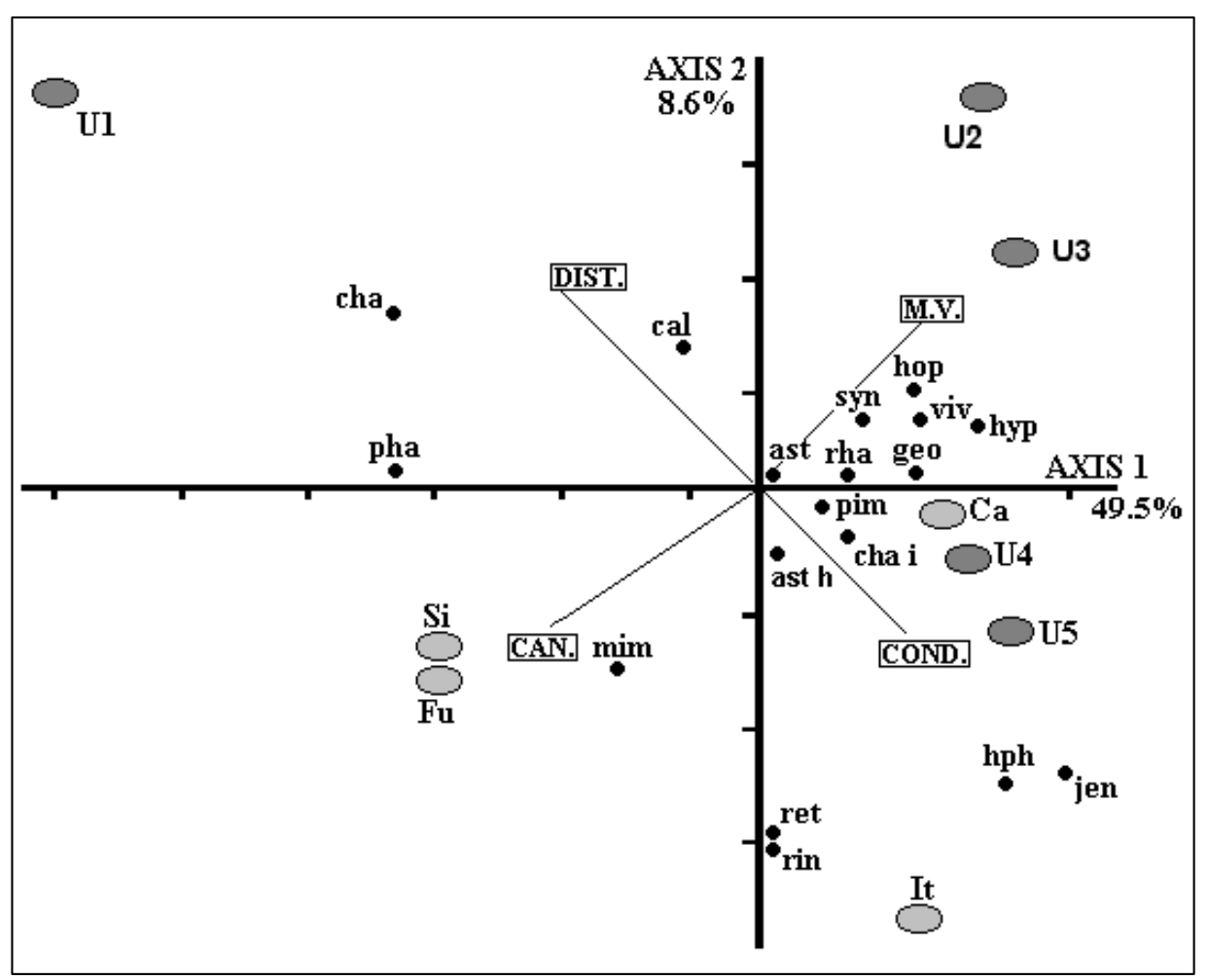

Figure 3 - Canonical Correspondence Analisys for specific densities in the 9 studied sites in the Ubatiba fluvial system. COND. = conductivity, CAN. = canopy, DIST. = distance from the river mouth, M.V. = marginal vegetation, ast $=$ A. janeiroensis, ast $\mathrm{h}=$ A. hastatus, pha $=P$. caudimaculatus, cal $=C$. calichthys, cha $\mathrm{i}=C$. interruptum, cha $=$ Characidium sp., geo $=G$. brasiliensis, $\mathrm{hph}=H$. reticulatus, hop $=H$. malabaricus, hyp $=H$. cf. punctatus, jen $=J$. multidentata, $\operatorname{mim}=M$. microlepis, pim $=P$. lateristriga, ret $=P$. reticulata, viv $=P$. vivipara, rha $=$ Rhamdia sp., rin $=$ Rineloricaria sp. e syn $=S$. marmoratus. 
Table 2 - Mean values of the sampled area $\left(\right.$ Area $\left(\mathrm{m}^{2}\right)$ ); percentage of occurrence of the environmental parameters splitted in three categories: (i) water dynamics - Pools, Rifles and Runs; (ii) kind of substrata - Mud, Sand, Gravel, Rock and (iii) riparian vegetation - CAN. and M.V. obtained from transects of $5 \mathrm{~m}$ apart during the seven sampling periods (Jul/94, Sep/94, Nov/94, Jan/95, Mar/95, May/95 and Jul/95) in the nine studied sites (U1, ...U5, Si, Ca, Fu, It) of the Ubatiba system. CAN. = canopy, M.V. = marginal vegetation, DIST. $=$ distance from the river mouth and COND. = conductivity.

\begin{tabular}{lrrrrrrrrr}
\hline & U1 & \multicolumn{1}{c}{ U2 } & \multicolumn{1}{c}{ U3 } & \multicolumn{1}{c}{ U4 } & \multicolumn{1}{c}{ U5 } & \multicolumn{1}{c}{ Si } & \multicolumn{1}{c}{ Ca } & \multicolumn{1}{c}{ Fu } & It \\
\hline Area $\left(\mathrm{m}^{2}\right)$ & 195.9 & 137.3 & 112.6 & 133.3 & 113.4 & 99.9 & 89.7 & 82.3 & 93.1 \\
Pools & 19.3 & 13.4 & 13.0 & 9.7 & 8.0 & 22.0 & 22.0 & 50.0 & 0.0 \\
Rifles & 70.7 & 48.7 & 15.0 & 85.7 & 74.7 & 50.7 & 7.5 & 50.0 & 98.5 \\
Runs & 10.0 & 37.9 & 72.0 & 4.6 & 17.3 & 27.3 & 70.5 & 0.0 & 1.5 \\
Mud & 11.0 & 9.2 & 8.5 & 8.0 & 4.3 & 21.1 & 20.3 & 35.0 & 6.3 \\
Sand & 31.7 & 24.0 & 9.0 & 37.1 & 69.7 & 26.3 & 32.3 & 45.9 & 23.2 \\
Gravel & 52.3 & 56.0 & 69.3 & 52.9 & 26.0 & 51.4 & 29.7 & 19.1 & 59.2 \\
Rock & 5.0 & 10.8 & 13.2 & 2.0 & 0.0 & 1.2 & 17.7 & 0.0 & 11.3 \\
CAN. & 95.0 & 0.0 & 0.0 & 15.0 & 7.0 & 90.0 & 0.0 & 93.0 & 90.0 \\
M.V. & 5.0 & 100.0 & 100.0 & 85.0 & 93.0 & 10.0 & 100.0 & 7.0 & 10.0 \\
DIST. $(\mathrm{m})$ & 15.0 & 13.0 & 9.0 & 7.5 & 1.5 & 13.5 & 10.0 & 5.0 & 3.0 \\
COND. $\left(\mu\right.$ S.c. $\left.{ }^{-1}\right)$ & 83.0 & 93.0 & 110.0 & 160.0 & 390.0 & 105.0 & 240.0 & 233.0 & 235.0 \\
\hline
\end{tabular}

Table 3 - Monte Carlo data for the eigenvalues of 999 randomisations for species matrix.

\begin{tabular}{cccccc}
\hline & Observed Data & \multicolumn{3}{c}{ Randomised Data } \\
\hline AXIS & Eigenvalues & Mean & Min & Max & P \\
Axis 1 & 0.521 & 0.242 & 0.064 & 0.494 & $0.001^{*}$ \\
Axis 2 & 0.091 & 0.114 & 0.042 & 0.230 & 0.798 \\
Axis 3 & 0.057 & 0.061 & 0.023 & 0.142 & 0.568 \\
\hline
\end{tabular}

The relationship between community structure and environmental variables was analysed through the Canonical Correspondence Analysis - CCA - (Ter Braak, 1986; PC-ORD - version 3.0, McCune and Mefford, 1997) and tested through Monte Carlo randomisation statistics (Manly, 1991).

\section{RESULTS}

Twenty-two species were registered in the Ubatiba system (Table 1). Characiformes were the most abundant $(36 \%)$ followed by Siluriformes and Cyprinodontiformes (23\% each), Perciformes (14\%) and Synbranchiformes (5\%). Except for A. tajasica, $H$. reticulatus, $H$. bifasciatus, $R$. janeiroensis and Tilapia sp. that occurred occasionally (frequency $<15 \%$ during the sampling period), all the other species were constant (frequency $>85 \%$ during the sampling period).

Except for locality U1, located in the upper stream right above a waterfall of approximately $4 \mathrm{~m}$ high, with at least four species, all of the sampling localities presented between 11 and 18 species, largely distributed in the study area. Species diversity was relatively similar between the studied sites (Fig. 2), however, U5 (the nearest one to the river mouth) was the richest one due to four occasional species (H. reticulatus, H. bifasciatus, $R$. janeiroensis and Tilapia sp.) that participated with low densities in only one or two sampling periods.

In spite of the great similarity in the spatial diversity, differences between sites were observed when the environmental variables (Table 2) were considered. The CCA ordering of species, localities and environmental variables showed axis 1 explaining $49.5 \%$ of the total variability of the matrix, while axis 2 explained $8.9 \%$ (Fig. 3); the determination coefficient $\left(\mathrm{r}^{2}\right)$ was significant only for the first axis (Monte Carlo, Table 3).

Considering only the significant axis (axis 1), three groups were formed: the first one by U1, whose position was determined by two environmental variables, distance from the river mouth (Dist.) and canopy (Can.), and by 
Characidium sp., $C$. callichthys and $P$. caudimaculatus that were highly abundant in this site and rare in many others. Discrimination of this site could be justified by the presence of only four species and a $4 \mathrm{~m}$ high waterfall that isolated it from the others. The position of the second group (Silvado - Si and Fundo - Fu) was greatly influenced by canopy (Can.), M. microlepis and the distance from the river mouth (Dist.). This group was similar to $\mathrm{U} 1$ due to the abundance of canopy and because it shared three species with restricted distribution (Characidium sp., $P$. caudimaculatus and C. callichthys). Four sites of the main river (U2, U3, U4 and U5) plus Caboclo (Ca) and Itapeteiú (It) formed the third group. The environmental variables that characterized this group were the absence of canopy, the abundant marginal vegetation (M.V.), mainly in U2, U3 and $\mathrm{Ca}$ and conductivity (Cond.) in U5 and It. The last two localities were apart from the others because they shared exclusive species (Rineloricaria $s p$ and $H$. reticulatus); moreover, both localities presented high species density of restricted distribution ( $J$. multidentata in U5 and $P$. reticulata in It). Therefore, it was noticed that the environmental characteristics explained a significant percentage of the fish species distribution along the Ubatiba system.

\section{DISCUSSION}

Twenty-two species made up the Ubatiba ichthyofauna. As registered for many other streams from Serra do Mar (Uieda, 1984, Bizerril and Araújo, 1993; Britski et al., 1986, Castro and Casatti, 1997; Bizerril, 1994; Uieda and Barretto, 1999; Esteves and Lobón-Cerviá, 2001; Araujo and Garutti, 2003), the Characiformes was the best represented in the present study. Among the 22 registered species, four (18\%) were not identified and others, in the Characidae group, were referred as Incertae Sedis (Lima et al., 2003) due to a lack of conclusive work about their monophily. This revealed the scarce taxonomical information of fish fauna from South-America and support the findings of Vari and Malabarba (1998) about the needs of urgent studies on the South-American ichthyofauna.

The number of species registered at Ubatiba system was far from that registered for other streams of similar size in the Neotropics. According to Garutti (1988) and Pavanelli and
Caramaschi (1997) between 37 and 64 species made up the ichthyofauna of streams from the Paraná river basin. Lobón-Cerviá et al. (1994) registered 35 fish species in small streams of the Brazilian Pampa. A great number of these species were restricted to confluence areas of large fluvial basins and that local diversity was directly correlated to the number of species of the whole basin. On the other hand, studies on streamdwelling fishes communities from other coastal drainages (e.g. Castro and Casatti, 1997; Casatti and Castro, 1998; Uieda and Uieda, 2001) revealed similar number of species of that registered in the present study and confirmed that local diversity was strongly determined by the basin size (Margalef, 1983).

According to Winemiller and Leslie (1992) species diversity is positively correlated to environmental heterogeneity that increases inversely to the headwaters distance and determines species addition along the stream gradient (Eros et al., 2003). The addition of species and gradual modification of environmental variables, along a longitudinal succession, was the basis of the River Continuum Concept (Vannote et al., 1980) but was not confirmed in the present study. Except for U1 that was located just above a natural barrier, all the other studied sites presented similar number of species (11-18 species). Site U5, which was the nearest one to the river mouth presented the largest number of species (18 species), however, among these, four species ( $H$. bifasciatus, $H$. reticulatus, Rineloricaria sp., $R$. janeiroensis and Tilapia sp.) had eventual occurrence related to the transportation processes from the marginal lagoons during the local spates.

Thus, as previously shown, environmental characteristics explained a great part of fish distribution along the Ubatiba system (Mazzoni and Lobón-Cerviá, 2000). Aranha and Caramaschi (1997) found that the four Cyprinodontiformes that occurred in the Ubatiba system had their distribution hardly explained by environmental variables. Mazzoni and Iglesias-Rios (2002) found that the distribution pattern of different species from the Ubatiba system were determined by the occurrence of canopy, marginal vegetation and the presence of pools and clay substratum. Menezes and Caramaschi $(1994 ; 2000)$ reported that the occurrence of juveniles of Hypostomus cf. punctatus was associated with marginal vegetation. Spatial segregation according to environmental requirements of young and adults 
of different species was also registered by Menezes and Caramaschi (2000) and Mazzoni et al (2004).

The Ubatiba system does not present a marked gradient along its longitudinal course, neither in terms of species composition nor in terms of environmental characteristics (except for conductivity). Water volume is relatively constant along the whole fluvial system, possibly due to its small sized tributaries (reduced drainage basin) as well as the small altitude difference between headwaters and mouth $(\sim 100 \mathrm{~m})$; moreover, substratum and water velocity is patchily distributed along the river. These associated factors determine that the community structure of each locality is independent from the longitudinal succession theoretically expected and hardly explained by local environmental characteristics.

\section{ACKNOWLEDGEMENTS}

We thank the staff of Laboratório de Ecologia de Peixes (UFRJ and UERJ) for help in the field and laboratory and to Chiara Mazzoni for the English translation. Dr. J. Lobón-Cerviá gave valuable comments on an earlier draft. This wok is part of the $\mathrm{PhD}$ thesis of the senior author and was partially supported by CNPq.

\section{RESUMO}

Vinte e duas espécies foram registradas no sistema fluvial do Ubatiba com predominância de Characiformes e Siluriformes seguidos de Cyprinodontiformes, Perciformes e Synbranchiformes. Dentre essas espécies 4 foram ocasionais com 1 ou 2 exemplares amostrados e restritas a 1 ou 2 das nove localidades estudadas; as demais 18 espécies foram constantes com altas densidades em pelo menos 1 localidade. A maioria das localidades estudadas apresentou entre 11 e 18 espécies, todas amplamente distribuídas; como exceção tem-se a localidade mais alta, localizada acima de um queda d'água de $4 \mathrm{~m}$, onde foram registradas apenas 4 espécies e a localidade mais próxima da desembocadura que apresentou 18 espécies. A Análise Canônica de Correspondência indicou que as variáveis ambientais explicaram grande parte dos padrões de densidade e distribuição das espécies de peixe e mostrou que a estrutura das comunidades de cada localidade é independente da sucessão longitudinal, teoricamente esperada pelo River Continuum Concept, e fortemente explicada pelas características ambientais.

\section{REFERENCES}

Angermeier, P. L. and Karr, J. R. (1984), Fish communities along environmental gradients in a system of tropical streams. Environmental Biology of Fishes, 9, 117-135.

Aranha, J. M. and Caramaschi, E. P. (1997), Distribuição longitudinal e ocupação espacial de quatro espécies de Cyprinodontiformes no rio Ubatiba, Maricá, RJ, Brasil. Acta Biológica Paranaense, 26, 125-140.

Araujo, R. B. and Garutti, V. (2003), Ecology of a stream from upper Paraná River basin inhabited by Aspidoras fuscoguttatus Nijssen \& Isbrücker, 1976 (Siluiformes, Callichthydae). Brazilian Journal of Biology, 63, 363-372.

Bayley, P. B. and Li, H. W. (1992), Riverine fishes. In: Calow, P. and Petts, G. E. (Eds.). The river handbook. Hydrological and ecological principles. London: Blackwell Scientific Publications.

Bizerril, C. R. S. F. (1994), Análise taxonômica e biogeográfica da ictiofauna de água doce do leste brasileiro. Acta Leopoldensia, 16, 51-80.

Bizerril, C. R. S. F. and Araújo, P. M. C. (1993), Composição e distribuição da ictiofauna do alto rio Pardo, na região de reservatório Euclides da Cunha, São Paulo, Brasil. Brazilian Archives of Biology and Technology, 36, 13-27.

Britski, H. A.; Sato, Y. and Rosa, A. B. S. (1986), Manual de Identificação de Peixes da Região de Três Marias. Brasília : CODEVASP.

Casatti, L. and Castro, R. M. C. (1998), A fish community of the Sâo Francisco River headwaters riffles, southeastern Brazil. Ichthyological Exploration of Freshwaters, 9, 229-242.

Castro, R. M. C. and Casatti, L. (1997), The fish fauna from a small forest stream of the Paraná river Basin, southeastern Brazil. Ichthyological Explorations of Freshwaters, 7, 337-352.

Eros, T; Botta-Dukát, Z and Grossman, G. D. (2003), Assemblage structure and habitat use of fishes in a Central European submontane stream: a patch-based approach. Ecology of Freshwater Fish, 12, 141-150.

Esteves, K. E. and Lobón-Cerviá, J. (2001), Composition and trophic structure of a fish community of a clear water Atlantic rainforest stream in southeastern Brazil. Environmental Biology of fishes, 62, 429-440. 
Garutti, V. (1988) Distribuição longitudinal da ictiofauna em um córrego da região noroeste do estado de São Paulo, bacia do rio Paraná. Revista Brasileira de Biologia, 48, 747-759.

Giller, P. S. and Malmqvist, B. (2001), The Biology of Stream and Rivers. Oxford: Oxford University Press.

Lima, F. C. T.; Malabarba, L. R.; Buckup, P. A.; Silva, J. F. P.; Vari, R. P.; Harold, A.; Benine, R.; Oyakawa, O. T.; Pavanelli, C. S.; Menezes, N. A.; Lucena, C. A. S.; Malabarba, M. C. S. L.; Lucena, Z. M. S.; Reis, R. E.; Langeani, F.; Casatti, L.; Bertaco, V. A.; Moreira, C. and Lucinda, P. H. F. (2003), Genera Incertae Sedis in Characidae. In: Reis, R. E.; Kullander, S. O. and Ferraris-Jr., C. J. (Orgs.). Check List of the Freshwater Fishes of South and Central America. Porto Alegre: EDIPUCRS. pp. 106-169.

Lobón-Cerviá, J.; Utrilla, C. and Querol, H. (1994), An evaluation of the 3-removal method with electrofishing techniques to estimate fish number in streams of the Brazilian Pampa. Archive für Hydrobiologie, 130, 371-381.

Manly, B. F. J. (1991), Randomization and Monte Carlo methods in biology. London : Chapman \& Hall.

Margalef, R. (1983), Limnología. Barcelona : Ediciones Omega.

Matthews, W. J. (1998), Patterns in freshwater fish ecology. New York : Chapman \& Hall.

Mazzoni, R. and Lobón-Cerviá, J. (2000), Longitudinal structure, density and production rates of a Neotropical stream fish assemblage: the river Ubatiba in the Serra do Mar (South-East Brazil). Ecography, 23, 588-602.

Mazzoni, R. and Iglesias-Rios, R., (2002), Distribution pattern of two fish species in a coastal stream in the Southeast of Brazil. Brazilian Journal of Biology, 62, $1-8$.

Mazzoni, R.; Schubart, S. A. and Iglesias-Rios, R. (2004), Longitudinal segregation of Astyanax janeiroensis in Rio Ubatiba: a Neotropical stream of south-east Brazil. Ecology of Freshwater Fish, 13, 231-234.

McCune, B. and Mefford, M. J. (1997), PC-ORD. Multivariate Analysis of Ecological Data. Version 3,0.MjM Software Design. Oregon : Gleneden Beach.

Menezes, N. A. (1992), Sistemática de peixes. In: Agostinho, A. A. and Benedito-Cecilio, E. (eds.). Situação atual e perspectivas da ictiologia no Brasil. Documentos do IX Encontro Brasileiro de Ictiologia. Maringá : Editora da UEM. pp 18-28.

Menezes, M. S. D. and Caramaschi, E. P. (1994), Características reprodutivas de Hypostomus gr. $H$. punctatus no rio Ubatiba, Maricá, RJ (Osteichthyes, Loricariidae). Revista Brasileira de Biologia, 54, 503-513.
Menezes, M. S. D. and Caramaschi, E. P. (2000), Longitudinal distribution of Hypostomus punctatus (Osteichthyes, Loricariidae) in a coastal stream from Rio de Janeiro, southeastern Brazil. Brazilian Archives of Biology and Technology, 43, 221-227.

Pavanelli, C. S. and Caramaschi, E. P. (1997), Composition of the ichthyofauna of two small tributaries of the Paraná river, Porto Rico, Paraná state, Brazil. Ichthyological Explorations of Freshwaters, 8, 23-31.

Reis, R. E. (1992), Serão suficientes os sistematas de peixes neotropicais? In: Agostinho, A. A. and Benedito-Cecilio, E. (Eds.). Situação atual $e$ perspectivas da ictiologia no Brasil, Documentos do IX Encontro Brasileiro de Ictiologia. Maringá : Editora da UEM. pp 29-38.

Ter Braak, C. J. F. (1986), Canonical correspondence analysis: a new eigenvector technique for multivariate direct gradient analysis. Ecology, 67, 1167-1179.

Uieda, V. (1984), Ocorrência e distribuição dos peixes em riacho de água doce. Revista Brasileira de Biologia, 44, 203-213.

Uieda, V. S. and Barretto, M. G. (1999), Composição da ictiofauna de quatro trechos de diferentes ordens do rio Capivara, Bacia do Tietê, Botucatu, São Paulo. Revista Brasileira de Zoociências, 1, 55-67.

Uieda, V. S. and Uieda, W. (2001), Species composition and spatial distribution of a stream fish assemblage in the east coast of Brazil: comparison of two field study methodologies. Brazilian Journal of Biology, 6, 377-388.

Vannote, R. L.; Minshall, G. W.; Cummins, K. W.; Sendel, J. R. and Cushing, C. E. (1980), The river continuum concept. Canadian Journal of Fisheries and Aquatic Sciences, 37, 130-138.

Vari, R. P. and Malabarba, L. R. (1998), Neotropical Ichthyology: An Overwiew. In: Malabarba, R. L.; Reis, R. E.; Vari, R. P.; Lucena, Z. M. S. and Lucena, C. A. S. (Eds.). Phylogeny and Classification of Neotropical Fishes. Porto Alegre: EDIPUCRS. pp. 1-11.

Winemiller, K. O. and Leslie, M. A. (1992), Fish assemblage across a complex tropical freshwater/marine ecotone. Environmental Biology of Fish, 34, 29-50.

Zippin, C. (1958), The removal method of population estimation. Journal of Wildlife Management, 22, 82-90.

Received: October 07, 2004; Revised: March 02, 2005; Accepted: July 28, 2005. 